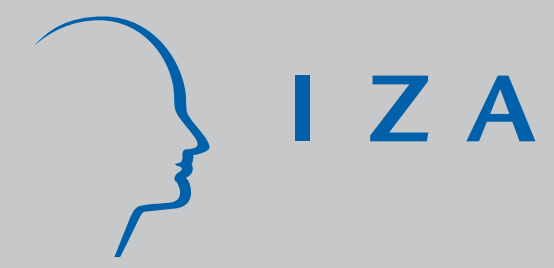

IZA DP No. 1394

Nascent Entrepreneurs in German Regions:

Evidence from the

Regional Entrepreneurship Monitor (REM)

Ingo Lückgen

Dirk Oberschachtsiek

Rolf Sternberg

J oachim Wagner

November 2004 


\title{
Nascent Entrepreneurs in German Regions: Evidence from the Regional Entrepreneurship Monitor (REM)
}

\author{
Ingo Lückgen \\ University of Cologne \\ Dirk Oberschachtsiek \\ Institute for Employment Research (IAB) \\ Rolf Sternberg \\ University of Cologne \\ Joachim Wagner \\ University of Lueneburg \\ and IZA Bonn
}

Discussion Paper No. 1394

November 2004

\author{
IZA \\ P.O. Box 7240 \\ 53072 Bonn \\ Germany \\ Phone: +49-228-3894-0 \\ Fax: +49-228-3894-180 \\ Email: iza@iza.org
}

\begin{abstract}
Any opinions expressed here are those of the author(s) and not those of the institute. Research disseminated by IZA may include views on policy, but the institute itself takes no institutional policy positions.

The Institute for the Study of Labor (IZA) in Bonn is a local and virtual international research center and a place of communication between science, politics and business. IZA is an independent nonprofit company supported by Deutsche Post World Net. The center is associated with the University of Bonn and offers a stimulating research environment through its research networks, research support, and visitors and doctoral programs. IZA engages in (i) original and internationally competitive research in all fields of labor economics, (ii) development of policy concepts, and (iii) dissemination of research results and concepts to the interested public.
\end{abstract}

IZA Discussion Papers often represent preliminary work and are circulated to encourage discussion. Citation of such a paper should account for its provisional character. A revised version may be available directly from the author. 
IZA Discussion Paper No. 1394

November 2004

\section{ABSTRACT \\ Nascent Entrepreneurs in German Regions: Evidence from the Regional Entrepreneurship Monitor (REM)*}

Nascent entrepreneurs are people who are (alone or with others) actively engaged in creating a new venture and who expect to be the owner or part owner of this start-up. Given that newly founded firms are important for the economic development of nations and regions, and that nascent entrepreneurs are by definition important for the foundation of new firms, information about nascent entrepreneurs is important for understanding crucial aspects of the economy. The relevance of detailed information on nascent entrepreneurs at the regional level, and the lack of it for Germany, let us start the research project Regional Entrepreneurship Monitor (REM) Germany in 2000. As part of this project, we performed a representative survey of the adult population in 10 German regions, plus a survey and interviews with local experts in the field of entrepreneurship in 2001. A second wave followed in 2003. This paper summarizes our findings using data from these surveys and interviews.

JEL Classification: J23

Keywords: $\quad$ nascent entrepreneurs, Regional Entrepreneurship Monitor, Germany

Corresponding author:

Joachim Wagner

Institute of Economics

University of Lueneburg

Campus 4.210

21332 Lueneburg

Germany

Email: wagner@uni-lueneburg.de

\footnotetext{
${ }^{*}$ Research for this paper was done as part of the project Regional Entrepreneurship Monitor (REM) Germany financially supported by the Deutsche Forschungsgemeinschaft (DFG) under grants STE 628/7-1/2 (Rolf Sternberg) and WA 610/2-1/2 (Joachim Wagner).
} 


\section{Introduction}

Nascent entrepreneurs are people who are (alone or with others) actively engaged in creating a new venture and who expect to be the owner or part owner of this start-up. Given that newly founded firms are important for the economic development of nations and regions, and that nascent entrepreneurs are by definition important for the foundation of new firms, information about nascent entrepreneurs is important for understanding crucial aspects of the economy. This information, however, can not be found in publications from official statistics. Until the turn of the millennium, therefore, we knew next to nothing about nascent entrepreneurs in Germany. The situation improved considerably when results from the first German wave of the Global Entrepreneurship Monitor (GEM) survey became available in 1999. ${ }^{1}$ The GEM project, however, is focussed on variations of entrepreneurial activity between entire countries. The relevance of detailed information on nascent entrepreneurs at the regional level, and the lack of it for Germany, let us start the research project Regional Entrepreneurship Monitor (REM) Germany in 2000. As part of this project, we performed a representative survey of the adult population in 10 German regions, plus a survey and interviews with local experts in the field of

\footnotetext{
${ }^{1}$ In the long-term "Global Entrepreneurship Monitor (GEM)" research project, which was created in 1998 (pilot phase, first data available for 1999), an international team of researchers documents and analyses the scope and causes of entrepreneurial activities and the complex relationship between entrepreneurship and economic growth in various countries and publishes the results each year (global reports and country reports). GEM started with ten participant countries; 31 countries were involved in the most recent study for 2003 (see www.gemconsortium.org. for details and all country reports and global reports). Germany is one of the six countries which have been involved in the GEM project from the very beginning. The German country team is led by the third author. The results of recent years have shown that entrepreneurial activities within a country are in statistical relationship with overall economic development and that interregional differences in entrepreneurial activities and attitudes are obvious (for further information on the GEM country reports Germany see http://www.wiso.uni-koeln.de/wigeo/, see also Sternberg, Bergmann and Lückgen 2004.). For the most recent global report of GEM see Reynolds et al. (2004).
} 
entrepreneurship. A second wave followed in 2003. This paper summarizes our findings using data from these surveys and interviews.

The rest of the paper is organized as follows: Section 2 reports the shares of nascent entrepreneurs in the adult population in ten German regions in 2001 and 2003, and presents some descriptive explanations on the reasons for regional variation based upon entrepreneurial framework conditions. In section 3 we deal with the question whether nascent entrepreneurs are different from the rest of the adult population, and whether there is a typical nascent entrepreneur with a typical set of characteristics. Here we describe the relationship between the prevalence rate of nascent entrepreneurs and selected personal characteristics. The following two sections summarize findings from our econometric investigations using the REM data: In section 4 we look at studies which focus on the ceteris paribus effect of personal characteristics (like being male, or coming from a family with at least one self-employed) on the one hand and regional characteristics (like density of population, or price of land) on the other hand on the propensity to become a nascent entrepreneur. Section 5 reviews findings from econometric studies which deal with selected special topics in nascent entrepreneurship: The role of gender and gender-specific differences in risk aversion; the professional background and Lazear's Jack-of-all-trades theory; the employment status of nascent entrepreneurs and differences among the unemployed, the employed and those out of the labor force; the role of failure as a selfemployed in the past and the taking of a second chance; and characteristics of the (former) workplace and the role of small, young firms as 'hothouses' for nascent entrepreneurs. Section 6 concludes by putting our findings into perspective and identifying open questions for future research.

\section{Nascent entrepreneurship in ten German regions: The evidence}

The data used in this paper are taken from the research project Regional Entrepreneurship Monitor (REM) (Bergmann, Japsen and Tamásy 2002; Lückgen and Oberschachtsiek 2004). REM focuses on the extent of the difference in entrepreneurial activities between regions in Germany, its determinants and consequences for regional development. The concept of the Regional Entrepreneurship Monitor is similar to that of the Global Entrepreneurship Monitor (GEM), a multi-country study that investigates the same topics at a national level (see footnote 1). 
Data collection was carried out in ten out of ninety-seven so-called planning regions or "Raumordnungsregionen" (Bundesamt für Bauwesen und Raumordnung 2001). Even if we can not claim that the data is representative for Germany as a whole, the regions were selected in such a way that they mirror the spatial structure with regard to old and new federal states (i.e. West and East Germany), highly industrialized versus more rural regions, center and periphery etc.. Information relating to the average in the selected regions can be considered to be a valid instrument for information on Germany as a whole. The regions included in the REM project are Cologne, Munich, Lueneburg, Middle Schleswig Holstein, Main-Rhoen, Stuttgart, Middle Hesse, Western Saxony/Leipzig, Emscher-Lippe and Middle Mecklenburg/Rostock (for detailed information regarding the selection of the regions see Lückgen and Oberschachtsiek 2004).

Data were collected in telephone surveys of the adult population, in mail surveys of local entrepreneurship experts, and in face-to-face interviews with selected experts in the regions.

The two REM telephone surveys of the German population aged 18-64 were conducted using computer assisted telephone interviewing by TNS EMNID (a leading German opinion research institute) in the summer of 2001 and 2003. In each of the ten regions a random sample of 1000 people was interviewed, leading to a data set with 20,000 cases. The random sampling process ensures that the sample is representative of the population in the respective region. The questionnaire asked for socio-demographic characteristics (sex, age, employment status, education, fields of professional experience, marital status, size of household and income) and a number of items related to entrepreneurial activities, e.g. whether the interviewee is the owner of a firm that is active and run by him or herself, or whether he or she is currently engaged in starting their own business. This data set gives a snapshot of activities and attitudes related to self-employment and new firm formation in the ten regions for the summers of 2001 and 2003.

In the population survey the interviewees were asked whether they, alone or with others, were actively involved in starting a new business that will as a whole or in part belong to them. It was also asked whether this business did not pay full wages or salaries for more 
than three months to anybody, including the interviewee. Those who answered in the affirmative are considered to be nascent entrepreneurs.

The mail survey of experts was carried out in each of the ten regions to investigate the impact of entrepreneurial framework conditions (EFCs) on regional entrepreneurial activities. Regional experts working in the field of entrepreneurship consulting, support and research were asked to complete a seven page questionnaire that provided a standardized measure of the EFCs. These framework conditions cover fields that affect entrepreneurial activities such as finance, physical infrastructure, government policy, government programs, technology transfer, entrepreneurial education, labor market, cultural and social norms, networks and female entrepreneurship (for details see Lückgen and Oberschachtsiek 2004).

The third type of data collected within the REM-project stems from the face-to-face interviews with six to eight selected experts in each region. These interviews contributed to the evaluation of regional EFCs, too, but they are especially helpful for a better interpretation of the results from the mail survey of experts by revealing special features of the regional entrepreneurial sector.

According to the population surveys the share of nascent entrepreneurs among adults aged 18 to 64 years in 2003 was 4.4 percent, and it was 0.8 percentage points higher than in 2001. Figure 1 reports detailed results for the ten regions in both years. Interregional differences in the order of magnitude point to differences in the level of entrepreneurial activity among the regions. The share of nascent entrepreneurs in 2003 is about twice as high in the regions of Cologne, Western Saxony/Leipzig and Munich as in the regions of Emscher-Lippe and Middle Mecklenburg/Rostock. The largest changes between 2001 and 2003 took place in the regions of Western Saxony/Leipzig, Middle Hessen, Munich and Stuttgart. In these regions the share of nascent entrepreneurs increased remarkably, e.g. in Western Saxony/Leipzig from 2.8 percent to 5.7 percent. 
Figure 1: $\quad$ Share of nascent entrepreneurs in the ten investigated regions in summer 2001 and 2003

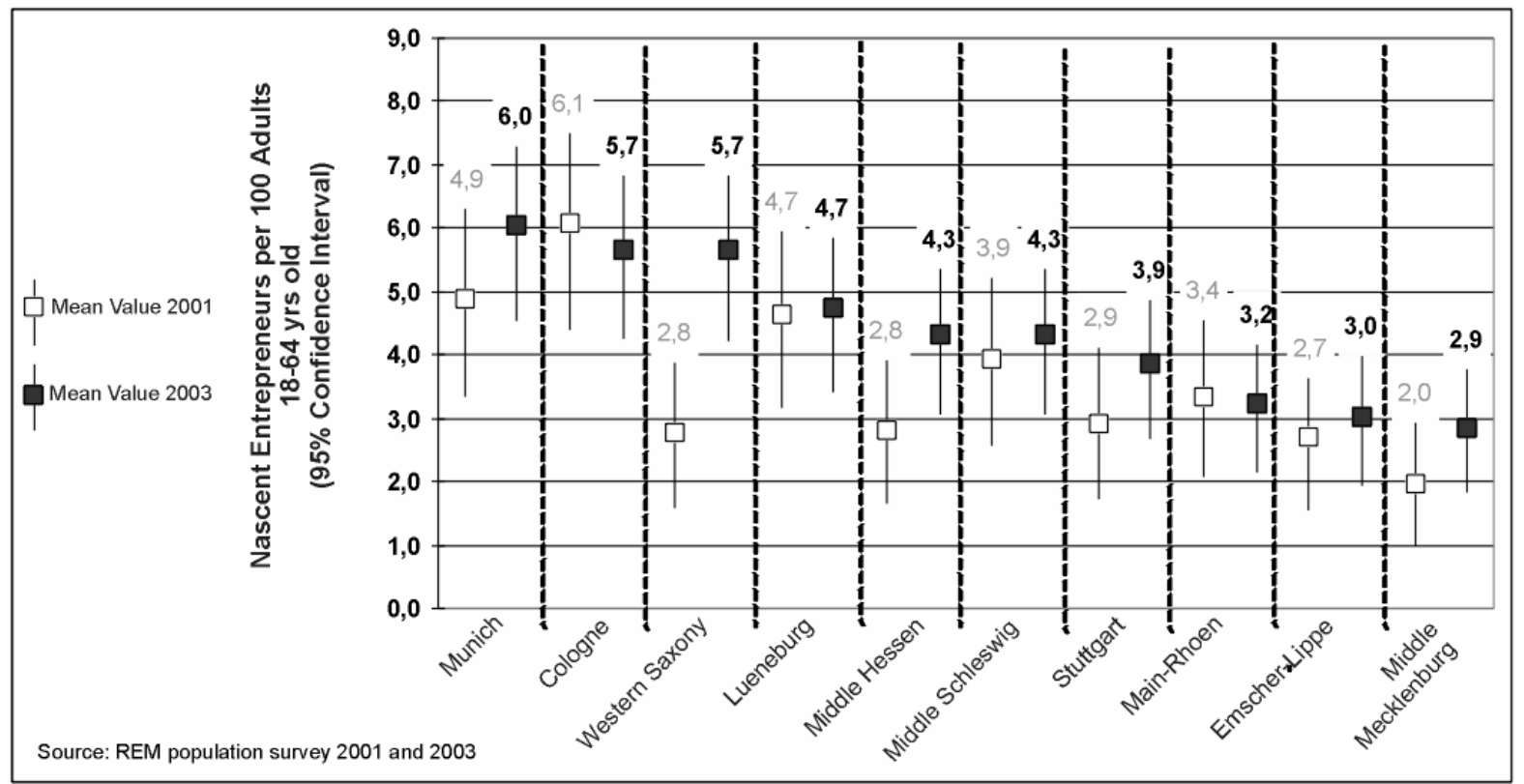

Why does the level of entrepreneurial activity differ between the ten regions? The REM project looks at two parameters influencing entrepreneurial activity: entrepreneurial attitudes and entrepreneurial framework conditions. Analyses for 2001 and 2003 show that on average people from regions with a high share of nascent entrepreneurs (e.g., Munich and Cologne) state that they have the skills necessary to found a new business more often, they are less risk averse, and they see better chances for a successful start of a business more often than interviewees from regions with lower shares of nascent entrepreneurs (e.g., Emscher-Lippe and Mecklenburg/Rostock). These results illustrate that there is a strong relationship between entrepreneurial attitudes in a region and the regional level of entrepreneurial activity. Compared to entrepreneurial attitudes the EFCs - information on which has been gathered in the mail surveys of the local entrepreneurship experts - have much less impact on the level of entrepreneurship activity in the regions (for details see Bergmann, Japsen and Támasy 2002, and Lückgen and Oberschachtsiek 2004).

\section{Who is a nascent entrepreneur?}

This section looks at the socio-demographic structure of nascent entrepreneurs. Here we discuss the question whether nascent entrepreneurs are different compared to the adult 
population as a whole. To do so we compare means and percentages for selected sociodemographic items. Given that we have information from two points of time we furthermore discuss the variation of these items over time for those variables that were measured identically in both surveys.

The evidence is reported in table 1. Note that the number of nascent entrepreneurs is small compared to the size of the sample as a whole. To take this into account we do not only report means and percentages for the items under investigation; the bounds of the 95 percent confidence intervals are displayed, too. ${ }^{2}$

[Table 1 near here]

Socio-demographic characteristics are captured by sex, age, martial status, education, employment status, household size and the net household income. Results are displayed for nascent entrepreneurs and the adult population. If possible these figures are reported for 2001 and 2003. To analyze the socio-demographic structure compare the percentages reported for nascent entrepreneurs and for the adult population. If there is no overlap of the confidence interval - displayed in brackets - the difference between the shares of the two groups are statistically significant at an error level of five percent. To look at variation over time, focus on the percentages reported for either nascent entrepreneurs or the adult population in different years.

To start we will focus on two basic socio-demographic characteristics, sex and age. First, concerning the adult population every second person is female. The share of females in the group of nascent entrepreneurs is statistically significantly lower in both years - 31.5 percent and $36.7 \%$ in 2001 and 2003, respectively. This supports the theses that females are less likely to start a new business. While the share of females among nascents increased between 2001 and 2003, the difference between the two years is statistically not significant. Second, while the adults are on average about 41.5 years old, the average

\footnotetext{
${ }^{2}$ The main target population interviewed in both years covers people aged between 18 and 64. However, in 2001 we interviewed people who were younger and older, too. Thus all interviewees who are not aged between 18 and 64 were dropped. This lead to a smaller sample size in 2001 compared to the 2003 sample.
} 
nascent entrepreneur is younger (38.5 years in 2001, 37.5 years in 2003). A look at the confidence intervals reveals that these differences in age are statistically significant at a conventional level.

Next we look at the marital status. We asked the interviewee if he or she is not married, married or divorced. Nascent entrepreneurs are more often single (not married) and less often divorced compared to the adult population. This difference, however, is statistically significant for the category "not married" only. Compared to the share in nascent entrepreneurs the share of unmarried people in the adult population is some eight percentage points lower in both years.

Third, we consider education. Note here that the items asked in the interview in 2001 and 2003 are different. In 2001 we asked for the highest exam passed only, while in 2003 the interviewee was asked to report every exam he or she passed. Table 1 lists the results for the 2003 survey. Statistically significant differences are found for three items: extended elementary school (Hauptschule), senior high school (A-level; German: Hochschulreife) and university (Hochschulabschluss). Nascent entrepreneurs are on average better educated than the adult population as a whole. For example, while the share of people in the adult population who finished extended elementary school is 28.6 percent this share is 22.2 percent only in the group of nascent entrepreneurs. Furthermore, while 53.3 percent of the nascent entrepreneurs hold an A-level, this share is much lower (41.5 percent) for the adult population as a whole. More than 46 percent of the nascent entrepreneurs hold a university diploma - almost 15 percentage points more than in the adult population as a whole.

Next, we look at the employment status of the individuals. Compared to the adult population as a whole nascent entrepreneurs are more often unemployed and less likely to be a housewife (or retired). While we observe a statistically significant and large difference in the share of people working full-time between nascent entrepreneurs and the adult population in 2001, this difference disappears in 2003. On the other hand the share of both part-time workers and unemployed among the nascents increased between 2001 and 2003. This indicates that part-time workers and the unemployed became a more important source of entrepreneurship (self-employment) recently. 
Last, we look at household size and net household income. To start with, the household size shows only small differences which are in most terms not statistically significant, too. As regards net household income the share of nascent entrepreneurs in the highest income class is higher compared to the adult population as a whole. Nascent entrepreneurs, therefore, tend to have a better financial background on average.

This evidence from the two waves of the Regional Entrepreneurship Monitor (REM) Germany shows that certain types of individuals are more likely to be involved in creating a new venture, but that individuals from all categories are involved to some extent. The evidence considered so far is, however, only descriptive in nature, and it does not reveal the extent to which the various factors are interrelated. To give just one example, take the relationship between gender and nascent entrepreneurship on the one hand, and between labor force status and nascent entrepreneurship on the other hand. Men are more often involved in creating new ventures than women, and so are people who are working full time compared to those who are not in the labor force. Given that the share of men who are in paid full-time employment is much higher than the share of women, what is the ceteris paribus effect of being male, and of working full time, on the propensity of being a nascent entrepreneur? Descriptive bivariate comparisons can not reveal this. Multivariate analyses that tackle this topic are reviewed in the next section.

\section{What makes a nascent entrepreneur? The role of personal and regional characteristics}

\subsection{The choice between paid employment and self-employment from an individual's perspective - some theoretical thoughts}

In section 4 we look at studies which focus on the ceteris paribus effect of personal characteristics (like being male, or coming from a family with at least one self-employed) on the one hand and regional characteristics (like density of population, or price of land) on the other hand on the propensity to become a nascent entrepreneur. ${ }^{3}$ While values for the first group of variables stem from survey data collected during the REM I phase in 2001,

\footnotetext{
${ }^{3}$ This section is based on parts of a previous publication by two of the authors (see Wagner and Sternberg 2004).
} 
values for the second group refers to publicly available data from secondary statistics (mainly from Bundesamt für Bauwesen und Raumordnung (BBR) 2001).

Empirical investigations of the ceteris paribus impact of individual and other characteristics and attitudes on the propensity to become a nascent entrepreneur are usually - either explicitely or implicitly - based on a theoretical framework that can be outlined as follows:

Consider a utility-maximizing individual that has the choice between paid employment and self-employment (taking the decision to participate in the labor market as given). This person will choose the option self-employment if the discounted expected life-time utility from self-employment $\left(D E L U^{\mathrm{s}}\right)$ is higher than that from paid employment $\left(\mathrm{DELU}^{\mathrm{p}}\right)$. The difference $\mathrm{N}_{\mathrm{i}}$ between DELU ${ }^{\mathrm{s}}$ and $\operatorname{DELU}^{\mathrm{p}}{ }_{\mathrm{i}}$,

(1) $\mathrm{N}_{\mathrm{i}}=\mathrm{DELU}_{\mathrm{i}}^{\mathrm{s}}-\mathrm{DELU}_{\mathrm{i}}^{\mathrm{p}}$

therefore, is crucial for the decision of individual $i$, and it will choose self-employment if $\mathrm{N}_{\mathrm{i}}$ is positive. DELU ${ }_{\mathrm{i}}^{\mathrm{s}}$ and $\operatorname{DELU}^{\mathrm{p}}{ }_{\mathrm{i}}$ are determined by the expected monetary and nonmonetary returns from self-employment and paid employment according to the utility function of the person and the individual's discount rate. Higher returns lead to higher values of DELU.

The expected monetary and non-monetary returns from both types of employment depend on variables related to individual $\mathrm{i}$, summarized in the vector $\mathrm{x}_{\mathrm{i}}$, and on variables related to the region $\mathrm{j}$ he lives in, collected in the vector $\mathrm{y}_{\mathrm{j}}$. The regional variables (i.e. the elements of $y_{j}$ ) include factors that are directly or indirectly influenced by future, current or past regional policy measures (like tax rates, quality of infrastructure, or the age structure of the population), and variables that are independent from regional policy (like natural climate or natural resources). Given that $\mathrm{N}_{\mathrm{i}}$ depends on $\operatorname{DELU}_{\mathrm{i}}^{\mathrm{S}}$ and $\operatorname{DELU}^{\mathrm{p}}{ }_{\mathrm{i}}$, and $\operatorname{DELU}_{\mathrm{i}}^{\mathrm{S}}$ and DELU $^{\mathrm{p}}{ }_{\mathrm{i}}$ depend on the monetary and non-monetary returns, $\mathrm{N}_{\mathrm{i}}$ can be written as a function of $x_{i}$ and $y_{j}$ : 
(2) $\mathrm{N}_{\mathrm{i}}=\mathrm{N}_{\mathrm{i}}\left(\mathrm{x}_{\mathrm{i}}, \mathrm{y}_{\mathrm{j}}\right)$

Note that we assume here that a person chooses between paid employment and selfemployment in the region he lives in. ${ }^{4}$ A rational individual will consider each region $\mathrm{j}(\mathrm{j}=$ $1, \ldots, \mathrm{k})$ and, given his individual characteristics and attitudes, compute $\operatorname{DELU}_{i}^{\mathrm{S}}$ and DELU $^{\mathrm{p}}{ }_{\mathrm{i}}$ for all $\mathrm{k}$ regions (taking the costs of moving to a region into account) to choose the region with the maximum among these $2 \mathrm{k}$ values. Given high monetary and nonmonetary costs of migration this often (but not always) means that a person will stay in the region he lives in - an empirically well-proved assumption for German entrepreneurs (see Sternberg et al. 1997).

Individual characteristics and attitudes (elements of $x_{i}$ ), and characteristics of the region (elements of $y_{j}$ ) including variables influenced by regional policy measures, which have a more positive or less negative impact on $\operatorname{DELU}_{i}^{\mathrm{S}}$ than on $\operatorname{DELU}^{\mathrm{p}}{ }_{\mathrm{i}}$ increase $\mathrm{N}_{\mathrm{i}}$ (and vice versa). Given that the expected monetary and non-monetary returns from both types of employment, the utility function, and the discount rate of an individual are unknown to an observer, we cannot observe $\mathrm{N}_{\mathrm{i}}$. Therefore, we cannot test directly whether an individual or regional characteristic - say, age of a person, regional tax rates, or population density in a region - has a positive impact on $\mathrm{N}_{\mathrm{i}}$ or not. If, however, $\mathrm{N}_{\mathrm{i}}$ is greater than the critical value zero, according to our theoretical framework a person will choose to become an entrepreneur, and the decision to do so or not is observable. In our empirical model we will investigate the influence of $x_{i}$ and $y_{j}$ on the probability that a person becomes an entrepreneur by looking at his known decision pro or contra.

\footnotetext{
${ }^{4}$ Note that by focussing on the factors affecting the decision to become self-employed, as opposed to remaining in paid-employment, instead of looking at differences in the probability that people are self-employed rather than employees, one avoids confounding entry and survival effects: The probability of being self- employed at a point in time depends on the probability of switching into self-employment in the past and then surviving as a self-employed until the time of the survey (see Parker 2004, p. 25f).
} 
The theoretical hypotheses regarding a positive or negative influence of personal characteristics and attitudes, and of characteristics of the region, on this decision are discussed below in sections 4.2 and 4.3 together with a description of the way the elements of $x_{i}$ and $y_{j}$ are measured. Then the empirical results of our econometric study are presented.

\subsection{An empirical model of the determinants of entrepreneurial activities}

In the theoretical model developed in section 4.1 the decision taken by person $\mathrm{i}$ to become a nascent entrepreneur or not is shaped by his personal characteristics and attitudes (collected in the vector $\mathrm{x}_{\mathrm{i}}$ ), and by characteristics of the region $\mathrm{j}$ he or she chose to live in (collected in vector $\mathrm{y}_{\mathrm{j}}$ ). In our empirical model we regress the observed decision of all persons from the REM survey aged between 18 and 68 on $\mathrm{x}$ and $\mathrm{y}$. Selection of the elements included in $\mathrm{x}$ and $\mathrm{y}$ are, at least in part, data driven. Although we had full control over the design of the questionnaire used in the REM survey, we were unable to collect information on all individual characteristics that are important for the decision under consideration due to budget constraints (that limited the time per interview and the number of items to be included) and the willingness of the interviewees to report information on issues like the amount of personal wealth, or losses in bankruptcies in the past. Effects of variables not included in the empirical model are covered by the error term. Frankly, this might lead to an omitted variables bias - a problem common to many (all?) econometric investigations.

That said, we will now turn to a discussion of the variables measured at the individual and at the regional level that are included in our empirical model. To start with the individual characteristics and attitudes, $\mathrm{x}_{\mathrm{i}}$ has the following elements:

- Sex (a dummy variable taking the value one if the interviewee is male). Hypothesis: It is a stylized fact that men do have a higher propensity to step into self-employment than women, in Germany as in all other GEM countries (see Reynolds et al. 2004). Sex is included in our empirical model to control for this difference in behavior between men and women, and we expect a positive sign for the estimated coefficient of the dummy variable. 
- Age (measured in years). Hypothesis: On the one hand, age is a proxy variable for personal wealth - the older a person is, the longer is the potential period to accumulate wealth. Given that young firms are often constrained by lack of credit because banks usually demand collateral to finance investments, a certain amount of wealth is crucial for starting a new business (see Evans and Jovanovic 1989). This leads to the expectation of a positive sign of the estimated coefficient of the age variable. On the other hand one has to acknowledge that starting a new business often leads to high sunk costs - think of all the effort to set up a business plan, doing market research, dealing with legal and administrative problems, etc. The shorter the expected life span of the new business, the shorter is the period over which these sunk costs can be earned back. To put it differently, setting up a new business with high sunk costs is more attractive at the age of 45 than at the age of 60 , ceteris paribus. This leads to the expectation of a negative sign of the estimated coefficient of the age variable. Given these two opposite influences of age on the propensity to become an entrepreneur it is an empirical question whether one dominates the other, or whether both net out (see Evans and Leighton 1989). Furthermore, it might be the case that the wealth effect dominates in the early years, while the sunk costs effect dominates towards the end of the active life, leading to an inversely $\mathrm{u}$-shaped relationship between age and the probability to become a nascent entrepreneur. To test for this nonlinear influence, age is also included in squares.

- Level of education (a dummy variable taking the value one if the interviewee has a higher education, i.e., went to school for at least 12 years, or holds a degree). Hypothesis: This dummy variable is a proxy for the amount of general human capital. Given that success in business demands knowledge in a number of different areas and a sufficient capacity to learn, we expect a positive relationship between higher education and the propensity to step into self-employment.

- Unemployment (a dummy variable taking the value one if the interviewee is unemployed). Hypothesis: Unemployment often acts as a push factor for building a new business. For Germany, this is amplified by the so-called bridging allowances paid by the labor services to help start-ups by (former) unemployed persons. Therefore, a positive coefficient of the dummy variable is expected (on unemployed nascent entrepreneurs in Germany, see Wagner 2003c). 
- Self-employed (a dummy variable taking the value one if the interviewee is selfemployed). Hypothesis: This dummy variable is a proxy for specific human capital related to running your own business, and a positive coefficient is expected (see Evans and Leighton 1989). Note that this variable should not be considered to be of a tautological nature. On the one hand today's self-employed can (and often do) step out of their business and opt for a job as a paid employee. On the other hand an owner of a business might decide to try another chance in a different area of business - in addition to or instead of the business he is running now.

- Failed as a self-employed in the past (a dummy variable taking the value one if an interviewee started - alone or with others - a business in the past that has been closed or given up and not sold to others later). Hypothesis: Like self-employed, this dummy variable is a proxy for specific human capital related to running your own business, and a positive coefficient is expected. Although stigmatization of those who failed once is often seen as a problem (at least, in Germany), taking a second chance is widespread (see Wagner 2003d).

- Personal contact with a young entrepreneur (a dummy variable taking the value one if the interviewee personally knows someone who started a new business during the last two years).Hypothesis: Contacts with young entrepreneurs will reduce costs because they make it easier to get answers to lots of 'how to' type questions related to a start-up. We expect a positive impact of contact with such a 'role model' (see Sternberg 2000, p. 60; Fornahl 2003). ${ }^{5}$

- Fear of failure a reason not to start (a dummy variable taking the value one if the interviewee agreed that fear to fail would prevent him from founding a firm). Hypothesis: If the interviewee answered this question in the affirmative we consider this as an indicator of a high degree of risk aversion, and we expect a negative impact on the probability of becoming a nascent entrepreneur (see Kihlstrom and Laffont 1979).

\footnotetext{
${ }^{5}$ Note that this 'cost reduction argument' still holds if contact to a young entrepreneur is endogenous in the sense that someone who has the idea to start a new firm may actively seek contacts with entrepreneurs to collect information.
} 
Descriptive statistics for these variables are given in the upper panel of Table 2. Among the nascent entrepreneurs we find more males, more people with higher education, more selfemployed, more who failed as a self-employed in the past, and with personal contact to a young entrepreneur, and less people who consider fear of failure to be a reason not to start a new business than among the rest of the adult population. Furthermore, nascent entrepreneurs are about 3.5 years younger on average. Note that the share of unemployed persons in both groups is the same.

[Table 2 near here]

Let us now turn to the regional characteristics included in our empirical model that constitute the vector $y_{j}$ :

- Population density (number of residents per square-kilometer in 1998). Hypothesis: Given that the lion's share of new firms is founded in services, a higher population density means more potential customers and higher demand in the region. This has a positive impact on the expected returns to a new business, and according to our theoretical framework we expect this to have a positive influence on the probability to become a nascent entrepreneur.

- Growth rate of population (1990-1998; percentages). Hypothesis: The higher is the growth rate of population, the higher is the rate of growth of demand for many services, and the better are the chances for newly founded businesses in these areas. Again, this has a positive impact on the expected returns, and, therefore, we expect it to have a positive influence on the probability to become a nascent entrepreneur.

- Average price of building plots (1996-1998; DM per square-meter). Hypothesis: The higher the price of land, the higher are the costs for building or renting a flat or shop, and given this negative impact of higher cost on returns we expect a negative impact of higher prices of building plots on the individual propensity to become a nascent entrepreneur.

- New firms per 1.000 residents (average 1998-2000). Hypothesis: This variable serves as a proxy for the regional entrepreneurial milieu. A high rate of new firm formation points to 
a climate that is favorable for start-ups in many ways (not measured by the other regional variables included here). Therefore, we expect a positive sign of the estimated coefficient.

- Ruling political party (a dummy variable that takes the value one if the Social Democratic Party together with its coalition partners was in a majority position in the regional government in 1997-2001, and zero if the Christian Democratic Union/Christian Social Union together with its coalition partners had the majority). Hypothesis: A social democratic regional government is often said to be less orientated towards business. According to this, a negative sign of the ruling party dummy has to be expected.

Descriptive statistics for these variables ${ }^{6}$ are given in the lower panel of Table 2. Note that on average all regional characteristics included in the empirical model have higher values for the group of nascent entrepreneurs compared to the rest of the adult population.

\subsection{Results of the econometric study}

The ceteris paribus role played by the elements of $x_{i}$ and $y_{j}$ in determining the probability of becoming a nascent entrepreneur is investigated in an econometric model with a dummy endogenous variable taking the value one if a person is a nascent entrepreneur, zero otherwise. When estimating the model the survey design has to be taken into account. The individuals in our sample are not sampled independently; persons stem from one of ten regions. Because of this sampling design, observations in the same region are not independent. If we use a standard probit model that assumes independence, the reported

\footnotetext{
${ }^{6}$ The source for population density, growth of population, and average price of building plots is Bundesamt für Bauwesen und Raumordnung (2001); figures for new firms per 1.000 residents are calculated from data reported in Statistisches Bundesamt (2001). Information on the government in the regions was collected by the authors. Note that the regional variables included in our model are not highly correlated. The highest correlation coefficient is 0.56 for population density and average price of building plots. Of the other nine correlation coefficients eight are less than 0.27 (in absolute values), and one population density ruling party - is 0.44 . The correlation matrix is available from the fourth author on request.
} 
standard errors may be too small. Accounting for clustering of observations in regions is necessary for "honest'" estimates of standard errors. Therefore we use the survey probit program svyprobit included in Stata 7.0 with the region as the cluster; see StataCorp (2001, p. 321). Note that spatial autocorrelation is not an issue in our study because the ten planning regions are scattered all over Germany. The estimation proceeds in three steps. In step one only personal characteristics and attitudes are included in the empirical model, i.e., the dummy variable for nascent entrepreneurship is regressed on xi only. Results are reported in the column headed 'Model A' in Table 3. From the prob-values ${ }^{7}$ it follows that according to this model, and in line with our priors, the probability of becoming a nascent entrepreneur is higher for males, people with higher education, unemployed, selfemployed, who failed as self-employed in the past, and who have personal contact with a young entrepreneur. It is lower for people with a high degree of risk aversion. All these estimated coefficients are significantly different from zero at the $6 \%$ level of error or better. The effect of age is less clear. The sign pattern points to an inversely u-shaped impact of age; the estimated coefficient of the age variable measured in levels is, however, not statistically significant at a conventional level.

[Table 3 about here]

Model A considers the role of personal attributes and attitudes only - and the results are confirmed by other studies based upon data collected during the REM I phase (see Bergmann 2004). From the descriptive evidence reported in figure 1 we know that the level of entrepreneurial activity differs considerably between regions. In step two, therefore, we additionally test for the role played by the region in determining whether a person becomes a nascent entrepreneur. Results for an augmented empirical model containing nine dummy variables for the regions (using the Emscher-Lippe region as the standard group) are reported in the column headed 'Model B' in table 3. All but one of the

\footnotetext{
${ }^{7}$ We report prob-values instead of t-values for two reasons: First, the degrees of freedom for the $t$ in svyprobit are the number of clusters (i.e., regions) minus one, and not the number of observations minus the number of estimated coefficients, and this might cause irritation; second, the prob-values give an immediate and exact impression of the empirical significance level of an estimated coefficient.
} 
estimated coefficients of the region dummies are highly significant statistically, and an adjusted Wald test of the null hypothesis that all these coefficients are zero rejects the null with a p-value of 0.0067 . Note that the estimated coefficients for the other variables included and their levels of significance do not differ much between Model A and Model B. In the third and final step the set of region dummies is replaced by the regional characteristics collected in the vector $\mathrm{y}_{\mathrm{j}}$. Results for this model are reported as 'Model C' in table 3. The big picture from the results for the personal characteristics and attitudes is the same as in Model A and B. With the exception of the ruling political party the characteristics of the regions all have the theoretically expected signs, and all estimated coefficients are statistically significant at the three percent level or better. According to the findings presented here, higher values of population density and growth, and a higher level of new firm formation intensity have a positive impact on the probability to become a nascent entrepreneur ceteris paribus, i.e., for a given set of personal characteristics and attitudes collected in vector $\mathrm{x}_{\mathrm{i}}$, while higher cost for building plots have a negative impact. Bergmann's study (2004) based upon REM data shows a similar statistical relevance of regional characteristics when he considers their impact on entrepreneurial attitudes and capabilities - and thus (however more in an indirect way) on start-up activities.

Discussion of results hitherto was limited to the statistical significance of the estimated coefficients and the direction of influence conducted by the variables. Information on the extent of this influence, or on the economic significance, however, is even more important. Evidently, a variable that has no statistically significant impact can be ignored from an economic point of view, but the opposite is not true: A variable that is highly significant statistically might not matter at all economically - if the estimated probability for becoming a nascent entrepreneur diminishes by $0.00001 \%$ when a person is 68 instead of 18 years old, we can ignore age of a person in any discussion on nascent entrepreneurs irrespective of any high level of statistically significance indicated by the prob-value. Unfortunately, the estimated coefficients from a probit model (or for any other non-linear model) can not easily be used for statements about the size of the ceteris paribus effect of a change of the value of an exogenous variable (e.g., an increase in the age of a person by five years) on the value of the endogenous variable (e.g., the probability of becoming a nascent entrepreneur), because the size of this effects depends on both the value of the exogenous variable under consideration and on the values of all other variables in the model (see Long and Freese 2001, p. 87). A way to ease interpretation of the estimation results is to 
compute the estimated values of the endogenous variable (here: the probability of becoming a nascent entrepreneur) for a person with certain characteristics and attitudes, and then to see how a change in the value of one exogenous variable at a time changes the estimated probability. For expository purposes, we define a reference person - call it person 1 - which is male, 40 years old, has higher education, is unemployed, does not consider fear of failure a reason not to start a new firm, has personal contact with a young entrepreneur, is not self-employed, did fail as a self-employed in the past, and lives in a (fictive) region where all regional variables have values at the sample mean. According to the results reported for model $\mathrm{C}$ in table 2 the estimated probability for person 1 to become a nascent entrepreneur is 0.216 . If we consider a person that is identical to person 1 but female (call it person 2), the estimated probability is 0.159 - much lower. The ceteris paribus impact of unemployment is comparable to the effect of sex - a non-unemployed person 3 has an estimated probability of 0.154 . If we look at person 4 who considers fear of failure to be a reason not to start a new firm, we get an estimated probability of 0.141 . The probability for person 5, who does not have personal contact with a young entrepreneur, is about half the estimate for person 1, i.e., 0.111. Person 6, who did not fail as a self-employed in the past, has an estimated probability of 0.106 that is about half as big as person 1.

Turning to the impact of the regional characteristics we will change the regional variables one at a time from their sample means to their sample maxima. If we do so for the population density, the estimated probability for person 8 increases to 0.273 compared to 0.216 for person 1. Setting the growth rate of population to its maximum gives a probability of 0.264 for person 9 . Setting the average price of building plots at the sample maximum leads to an estimated probability of 0.163 for person 10 . These simulation exercises (and many more not reported here) show that the variables which are statistically significant according to the results reported in table 3 are important from an economic point of view, too. The decision to become a nascent entrepreneur is related to the personal characteristics and attitudes, and to characteristics of the region, in a way that is consistent with our theoretical hypotheses. These results are confirmed by related studies of (some of) the authors of this paper based upon REM I data (see Sternberg and Wagner 2004, Wagner and Sternberg forthcoming). 


\section{Topics in research in nascent entrepreneurship}

Besides the papers that used the data collected in the Regional Entrepreneurship Monitor (REM) Germany project to investigate the question what makes a "typical" nascent entrepreneur and to identify personal and regional factors that are statistically significant for the decision to create a new venture or not, there are a number of econometric investigations that tackle more specific issues related to nascent entrepreneurship. This literature is reviewed below, starting with papers that focus on the ceteris paribus impact of one specific personal characteristic, and followed by studies that investigate the ceteris paribus impact of elements of the environment a person lives and works in.

Gender: In western industrialized countries men are on average more than twice as active in entrepreneurship as women. Little is known about precisely why this is the case. Based on the REM data Wagner (2004a) estimates an empirical model for the decision to become self-employed to test for differences between women and men in the ceteris paribus impact of several characteristics and attitudes, taking the rare events nature of becoming an entrepreneur into account. Furthermore, a non-parametric approach using Mahalanobisdistance matching of man and women who are as similar as possible is used to investigate the difference in the propensity to become self-employed by gender. The core finding of this empirical exercise is that considering fear of failure to be a reason not to start an own business has a much smaller negative influence on the propensity to step into selfemployment for men than for women - in other words, women tend to be much more risk averse than men.

Professional background: Recently, Edward Lazear (2002, 2004) proposed the jack-of-alltrades view of entrepreneurship. Based on a coherent model of the choice between selfemployment and paid employment he shows that having a background in a large number of different roles increases the probability of becoming an entrepreneur. The intuition behind this proposition is that entrepreneurs must have sufficient knowledge in a variety of areas to put together the many ingredients needed for survival and success in a business, while for paid employees it suffices and pays to be a specialist in the field demanded by the job taken. Lazear $(2002,2004)$ and Wagner (2003a) show that this theory is in line with empirical results for self-employed vs. paid employees in the U.S. and in Germany, respectively. Using the REM data Wagner (2003b) tests the jack-of-all-trades hypothesis 
for nascent entrepreneurs vs. persons who decide to continue working as paid employees. He finds evidence for a ceteris paribus positive impact of both the number of fields of professional experience and the number of professional degrees for the decision to become a nascent entrepreneur.

Employment status: Is nascent entrepreneurship different among the unemployed, the employed, and the not employed (i.e., those out of the labor force)? Wagner (2003c) investigates this topic using the REM data. A comparison of the results for the unemployed on the one hand and the employed / not employed on the other hand reveals some remarkable differences: While being male and having a higher education does not matter for the unemployed, it has a positive impact for the other two groups considered here. Age, however, only matters for the unemployed; and considering fear of failure a reason not to start has a negative impact for the employed only. The only individual variable that has the same statistically significant sign for all three groups is the personal contact with a young entrepreneur - the probability of becoming a nascent entrepreneur is higher for anybody with such a contact.

Failure in the past: Folklore has it that the comparatively low proportion of self-employed in Germany is in part due to a habit that might be termed "stigmatization of failure": taking a second chance to build one's own firm after failing as a self-employed person is said to be much more difficult here than in other countries. Wagner (2003d) uses the REM data to document that $8 \%$ of all people whose former firm went out of business are nascent entrepreneurs today, while the share of failed entrepreneurs among the nascent entrepreneurs is $23 \%$. He investigates the determinants of such a restart. It turns out that both individual and regional factors are important for taking a second chance: this probability is negatively related to age, a high risk aversion, and the share of persons in the region who failed in the past, while it is positively related to personal contacts with a young entrepreneur and the regional share of nascent entrepreneurs.

Characteristics of the (former) workplace: A stylized fact emerging from a vast number of empirical studies on the inter-regional differences in new firm formation is that the start-up rate in a region tends to be positively related to the share of employees working in small firms, or the proportion of small firms among all firms in the region. A similar point has been made in studies dealing with inter-industry differences in new firm formation. A 
theoretical explanation for this empirical regularity argues that working in a small firm tends to provide employees with a much more relevant experience for starting a new business (e.g., contacts with customers, and with the owner of the firm who therefore provides a role model to follow) than working in a large firm. If this arguments holds one should expect that people who are working in a small firm (or did so in the past) should have a higher propensity to step into self-employment than others who work(ed) for a large enterprise. A similar argument can be made for those who work(ed) in young firms compared to those in old firms: Through a close contact to a successful entrepreneur people in a young firm have the opportunity to gather information about the transition from paid employment to self employment with all its problems, and about possible solutions. The "employer-as-a-role-model" argument put forward in the context of the small firm should be even more relevant here, because not all small firms are young (and, therefore, not all owners of small firms are role models for potential starters of new firms today), but most of the young firms are small. And we expect it to be most relevant in the case of work experience gathered in young and small firms. Using the REM data Wagner (2004b) tests the hypothesis that young and small firms are hothouses for nascent entrepreneurs, controlling for various individual characteristics and attitudes. $\mathrm{He}$ finds that work experience in a firm that is both young and small is statistically significant and economically important for the decision to become a nascent entrepreneur.

The studies reviewed above that focus on the ceteris paribus impact of specific personal characteristics or on selected elements of the environment a person lives and works in on the decision to start creating a new venture shed some light on important aspects of nascent entrepreneurship. However, given that they each are based on a single data set from a single country, collected in a single point in time, it is an open question whether the results are valid in general. Hopefully, further research attempting to replicate these findings using different data sets will tell.

\section{Concluding remarks}

Five years ago we knew next to nothing about nascent entrepreneurs in Germany as a whole, and about inter-regional differences in nascent entrepreneurship activities. The analyses based on the rich data sets collected in the Regional Entrepreneurship Monitor (REM) Germany project helped to fill some of the gaps in our knowledge. From the 
empirical studies summarized above we have evidence how many nascent entrepreneurs are there, what makes a region more or less entrepreneurial, who the nascent entrepreneurs are, and what role is played ceteris paribus by personal and regional characteristics in determining the probability to become a nascent entrepreneur. Furthermore, we learned about the role of gender and gender-specific differences in risk aversion; the relevance of the professional background; differences among nascent entrepreneurs who are unemployed, employed and out of the labor force; the role of failure as a self-employed in the past and the taking of a second chance; and characteristics of the (former) workplace and the role of small, young firms as 'hothouses' for nascent entrepreneurs.

Obviously, there are many aspects related to nascent entrepreneurship in Germany that are still waiting for investigation. To point to a perspective for future research, we briefly mention some of the more important topics:

What do nascent entrepreneurs do? What are the activities nascent entrepreneurs are involved in when they are actively engaged in creating a new venture of their own? The only way to find out is to ask them, and this has been done in the U.S. in the Wisconsin Entrepreneurial Climate Study conducted in Spring 1993, in a national pilot study for the U.S. done in October / November 1993 (Reynolds 1997), and in the Panel Study of Entrepreneurial Dynamics (PSED) that started in 1998 (Gartner and Carter 2003). Furthermore, we have evidence from surveys conducted in Norway (Alsos and Ljunggren 1998) and in Canada ( Diochon et al. 2001); Wagner (2004c, section 3) summarizes the findings from these studies. Unfortunately, we do not have comprehensive and comparable evidence on the set of activities nascent entrepreneurs are involved in, and on the timing of these events, for Germany, because this is a topic that has neither been investigated in the Global Entrepreneurship Monitor project nor in REM. From the evidence we have on startup activities it is clear that there is neither a fixed set of events (although some events are more common than others) nor a uniform sequence. The industry, the region, and personal factors (like gender, skills, and financial reserves of the nascent entrepreneurs) all matter in determining what a nascent entrepreneurs does, and when.

What happens to nascent entrepreneurs, and why? Not all nascent entrepreneurs see their vision through to an eventual start-up in some given period of time (say, in a year after they outed themselves as nascent entrepreneurs in a survey) - some give up, and others are 
still trying. A number of studies for countries from North America (United States and Canada) and Europe (Austria, Germany, Italy, the Netherlands, Sweden and Norway) report empirical findings on the proportions of these sub-groups, and on variables that differentiate between them. Wagner (2004c) summarizes the findings and looks at differences and similarities across space. For Germany, Bahß, Lehnert and Reents (2003) use data from the KfW-Gründungsmonitor project to investigate how many of those persons who stated in April - July 2002 that they intend to step into self-employment during the next six month did so until February 2003. From the 300 participants in this follow-up survey $29 \%$ were indeed self-employed, $21 \%$ were still trying, $32 \%$ delayed their project, and $18 \%$ gave up. The authors mention that unemployed more often stop the process of setting up a new venture compared to paid employees, and that "starters" and "stoppers" do not differ in important personal characteristics like risk aversion and aspiration for independence; details, however, are not reported. Given that those who state in a survey that they intend to become self-employed in the next half year can not be considered to be nascent entrepreneurs according to the definition given in section 2 above, these findings are not strictly comparable to the results reported in other studies. However, they provide the only information available for Germany that at least comes close to, given that no longitudinal study on German nascent entrepreneurs has been done as yet (see Bergmann (2000) for a fruitless attempt to use the German household panel SOEP for an investigation of this topic).

How and why do migrants differ from non-migrants with respect to start-up activities? From international, comparative and empirical research like GEM it is well-known that entrepreneurial activities differ between migrants and inhabitants without any migration background (see, e.g., Harding 2004 for the UK). According to GEM data the total entrepreneurial activity rate (TEA) ${ }^{8}$ was $5.0 \%$ in Germany 2003 for 18-64 year old persons

${ }^{8}$ As described in previous section, within REM (and GEM) an individual may be considered a "nascent entrepreneur" based on three conditions: first, if he or she has done something - taken some action - to create a new business in the past year, if he or she expects to share ownership of the new firm; and, third, if the firm has not yet paid salaries and wages for more than three months. In cases where the firm already exists and the interviewee is the owner and he or she has paid salaries and wages for more than three but less than 42 months, it is classified as a "new business" and the individual is classified as a 
entitled to vote (as proxy for non-migrants), whereas among adults not entitled to vote (as a proxy for migrants) respective percentage was $9.9 \%$ ! Our hypothesis would be that such start-ups created by migrants are more unevenly distributed across German regions than start-ups created by non-migrants. From other research work it is known that this hypothesis is of empirical validity if such migrants are return migrants as Müller (2004) reports for Chinese return migrants. These return migrants can be responsible for a significant part of all entrepreneurial activities within a given region, as Saxenian (2000) has shown. However, it is assumed that such entrepreneurial behaviour of migrants differs between regions within Germany as well - given the uneven distribution of ethnic minorities between (and within) German regions and the ethnic-specific entrepreneurial activities. Due to the fact that the economic role of migrants will increase in all German regions in the future (however, to a different extent between the regions) it would be worthwhile to analyze empirically the role of start-ups by current and future migrants.

How and why do the locational preferences of nascent entrepreneurs and young entrepreneurs change over time? The spatial immobility of individuals which have started a firm is supported by empirical evidence based upon numerous studies (see Sternberg et al. 1997 for start-ups in German business incubators). However, much less is known about the relevance of this spatial immobility when firms are getting older. Due to an increasing importance of national and international demand (compared to local demand) and changed relevance of hard and soft locational factors a new firm location could be a reasonable reaction when start-ups grow (Meester 2004). On the other hand, young owner-managed firms still need their reliable local personal networks of friends, fools $\&$ families even if they are more established. With the help of panel studies it might be possible to shed an empirical light on the hypothesis that the relevance of intra-regional networks and spatial immobility decrease over time. Implications for the role of start-ups within a policy strategy of endogenous regional development (see Sternberg 2003) are obvious.

How, when and where should start-up policies support nascent entrepreneurs or potential nascent entrepreneurs? Finally, the available and future studies based upon REM data

\footnotetext{
"young entrepreneur". The TEA rate is the sum of the two previous measures; those persons who qualify as both a "nascent entrepreneur" and a "new business" are counted only once, however.
} 
potentially offer a variety of possibilities to develop recommendations for local and regional start-up policies. For some ten years now, there have been a large, and still increasing, number of promotional programs in Germany aimed explicitly or implicitly at supporting entrepreneurial activities. These programs, which take effect in Germany and its regions, have been established by the European Union, individual federal ministries (... for Economics and Labor, ... for Education and Research), ministries of the individual federal states and individual municipalities. First results with REM data show for the selected ten REM regions the statistical relationship between policy instruments and startup activities seems to be only modest (Sternberg forthcoming). However, much more empirical research is needed to recover the interdependent relationship between entrepreneurial activities and policy instruments to support start-ups. As shown before the REM regions are divided up on the basis of the 97 planning regions, which do not represent any official delineation of regions. Consequently, there are no entrepreneurship promotion programs which apply exclusively to individual REM regions. It is therefore not possible to evaluate existing public policy instruments directly using REM data. Significant research deficits exist in terms of time lags. The discussion of policy impacts on an individual's decisions and the intended regional development effects must be interpreted as a complex system of interdependent relationships between at least two factors. Entrepreneurial activities are the result of the personal perception of the entrepreneurial framework conditions (and the related policies) of the individuals living in a region - as explained in a previous section.

To conclude, and to put our own findings into perspective, we point out that stylized facts that could be most valuable for entrepreneurship researchers, policy makers, and, last but not least, nascent entrepreneurs, need to be based on results from a number of studies using large, comprehensive longitudinal data bases that are comparable across time and space, and that can be accessed by researchers for replication and extension of former studies. The Global Entrepreneurship Monitor (GEM) and the Panel Study of Entrepreneurial Dynamics (PSED) projects, and the data collected within these projects, are important steps towards this aim at the level of countries as a whole. The high importance of new firms for economic dynamics, and the high importance of nascent entrepreneurs for new firms, point to the need for further steps in the future. With a focus on the region and inter-regional differences in entrepreneurship activities inside countries, these steps should include 
further waves of the Regional Entrepreneurship Monitor (REM) Germany and comparable projects in other countries.

\section{References}

Alsos, Gry Agnete and Elisabet Ljunggren (1998). Does the Business Start-Up Process Differ by Gender? A Longitudinal Study of Nascent Entrepreneurs. Frontiers of Entrepreneurship Research. Babson College, Wellesley, MA.

Bahß, Christian, Nicole Lehnert and Nicola Reents (2003). Warum manche Gründungen nicht zustande kommen. KfW-Research, Nr. 10, Oktober, 2-9.

Bergmann, Heiko (2000). Gründungspotenzial und Gründungsengagement im Spiegel des Soziökonomischen Panels (SOEP). Essen: RWI.

Bergmann, Heiko (2004). Gründungsaktivitäten im regionalen Kontext. Gründer, Gründungseinstellungen und Rahmenbedingungen in zehn deustchen Regionen. Köln: Wirtschafts- und Sozialgeographisches Institut der Universität zu Köln (= Kölner Forschungen zur Wirtschafts- und Sozialgeographie, 57).

Bergmann, Heiko, Andrea Japsen and Chistine Tamásy (2002). Regionaler Entrepreneurship Monitor (REM). Gründungsaktivitäten und Rahmenbedingungen in zehn deutschen Regionen. Universität zu Köln, Universität Lüneburg.

Bundesamt für Bauwesen und Raumordnung (2001). Aktuelle Daten zur Entwicklung der Städte, Kreise und Gemeinden, Ausgabe 2000. Bonn: Bundesamt für Bauwesen und Raumordnung.

Diochon, Monica, Yvon Gasse, Teresa Menzies and Denis Garand (2001). From conception to inception: Initial findings from the Canadian Study on Entrepreneurial Emergence. London, Ontario: Proceedings of the Administrative Science Association of Canada, Entrepreneurship Division, Volume 22 (21), 41-51. May 26-29.

Evans, David S. and Boyan Jovanovic (1989). An estimated model of entrepreneurial choice under liquidity constraints. Journal of Political Economy 97: 808-827.

Evans, David S. and Linda S. Leighton (1989). Some empirical aspects of entrepreneurship. American Economic Review 79: 519-535. 
Fornahl, Dirk (2003). Entrepreneurial activities in a regional context. In: Fornahl, Dirk and T. Brenner (eds), Cooperation, networks and institutions in regional innovation systems. Cheltenham UK, Northampton MA: Edward Elgar, 38-57.

Gartner, William B. and Nancy M. Carter (2003). Entrepreneurial Behavior and Firm Organizing Processes. In: Zoltan J. Acs and David B. Audretsch (Eds.), Handbook of Entrepreneurship Research (International Handbook Series on Entrepreneurship, Volume 1). Boston etc.: Kluwer Academic Publishers, 195-221.

Harding, Rebecca (2004). Global Entrepreneurship Monitor United Kingdom 2003. London: London Business School.

Kihlstrom, Richard E. and Jean-Jaques Laffont (1979). A general equilibrium entrepreneurial theory of firm formation based on risk aversion. Journal of Political Economy 87: 719-748.

Lazear, Edward P. (2002). Entrepreneurship. National Bureau of Economic Research Working Paper 9109, August. [Download: www.nber.org/papers/w9109]

Lazear, Edward P. (2004). Balanced Skills and Entrepreneurship. American Economic Review - Papers and Proceedings 94 (2), 208-211.

Long, J. Scott and Jeremy Freese (2001). Regression models for categorical dependent variables using Stata. College Station, TX: Stata Press.

Lückgen, Ingo and Dirk Oberschachtsiek (2004). Regionaler Entrepreneurship Monitor (REM II 2003/2004). Zur Dynamik von Gründungsaktivitäten in Deutschland: Ausmaß und Ursachen. Universität zu Köln, Universität Lüneburg.

Meester, Wilhelm J. (2004). Locational Preferences of Entrepreneurs. Heidelberg, New York: Physica.

Müller, Claudia (2004). Entrepreneurship and Technology Transfer by Chinese Return Migrants - a Theoretical and Empirical Contribution to the Reverse Brain Drain Discussion. Cologne: Department of Economic and Social Geography (=Working Paper No. 2004-01).

Parker, Simon (2004). The Economics of Self-Employment and Entrepreneurship. Cambridge etc.: Cambridge University Press. 
Reynolds, Paul D. (1997). Who Starts New Firms? - Preliminary Explorations of Firms-inGestation. In: Small Business Economics 9, 449-462.

Reynolds, Paul D. et al. (2004). GEM Global Entrepreneurship Monitor. 2003 Executive Report. Kansas City: Ewing Marion Kauffman Foundation.

Saxenian, Annalee (2000). Silicon Valley's New Immigrant Entrepreneurs. Working Paper No. 15. San Diego: The Center of Comparative Immigration Studies.

StataCorp (2001). Stata User's Guide, Release 7. Stata Corporation, College Station, TX.

Statistisches Bundesamt (2001). Statistik regional, Ausgabe 2001, CD-ROM. Wiesbaden: Destatis.

Sternberg, Rolf (2000). Entrepreneurship in Deutschland. Das Gründungsgeschehen im internationalen Vergleich. Länderbericht Deutschland 1999 zum Global Entrepreneurship Monitor. Berlin: Edition sigma.

Sternberg, Rolf (2003). Das Konzept endogener Regionalentwicklung - Implikationen für Existenzgründungen und deren Förderung. In: Sternberg, Rolf (Hrsg.), Endogene Regionalentwicklung durch Existenzgründungen? Empirische Befunde aus Nordrhein-Westfalen. Hannover: Akademie für Raumforschung und Landesplanung (ARL), S. 4-19 (= Arbeitsmaterialien der ARL, 299).

Sternberg, Rolf (forthcoming). Entrepreneurship in German regions - empirical evidence from the Regional Entrepreneurship Monitor (REM). In: Audretsch, David and Heike Grimm (eds.): Local heroes in the global village, Boston etc.: Kluwer Academic Publishers.

Sternberg, Rolf, Heiko Bergmann and Ingo Lückgen (2004). Global Entrepreneurship Monitor (GEM). Länderbericht Deutschland 2003. Cologne: University of Cologne, Department of Economic and Social Geography.

Sternberg, Rolf and Wagner, Joachim (2004). The Decision to Start a New Firm: Personal and Regional Determinants. Empirical Evidence from the Regional Entrepreneurship Monitor (REM) Germany. In: Fritsch, Michael and Michael Niese (Eds.): Gründungsprozess und Gründungserfolg. Interdisziplinäre Beiträge zum Entrepreneurship Research. Heidelberg: Physica, p. 19-38. 
Sternberg, Rolf et al. (1997). Bilanz eines Booms - Wirkungsanalyse von Technologieund Gründerzentren in Deutschland. Dortmund: Dortmunder Vertrieb für Bau- und Planungsliteratur (2nd edition).

Wagner, Joachim (2003a). Testing Lazear's Jack-of-All-Trades View of Entrepreneurship with German Micro Data. Applied Economics Letters 10, p. 687-89.

Wagner, Joachim (2003b). Are Nascent Entrepreneurs Jacks-of-All-Trades? A Test of Lazears's Theory of Entrepreneurship with German Data. Institute for the Study of Labor IZA Discussion Paper No. 911.

Wagner, Joachim (2003c). The Impact of Personal Characteristics and the Regional Milieu on the Transition from Unemployment to Self-Employment: Empirical Evidence for Germany. Jahrbücher für Nationalökonomie und Statistik 223, p. 204-222.

Wagner, Joachim (2003d). Taking a Second Chance: Entrepreneurial Re-starters in Germany. Applied Economics Quarterly 49, p. 255-272.

Wagner, Joachim (2004a). What a Difference a Y Makes: Female and Male Nascent Entrepreneurs in Germany. Institute for the Study of Labor IZA Discussion Paper No. 1134, May.

Wagner, Joachim (2004b). Are Young and Small Firms Hothouses for Nascent Entrepreneurs? Evidence from German Micro Data. Institute for the Study of Labor IZA Discussion Paper No. 989, January.

Wagner, Joachim (2004c). Nascent Entrepreneurs. Institute for the Study of Labor IZA Discussion Paper No. 1293, September.

Wagner, Joachim and Rolf Sternberg (2004). Start-up activities, individual characteristics, and the regional milieu: Lessons for entrepreneurship support policies from German micro data. Annals of Regional Science 38, p. 219-240.

Wagner, Joachim and Rolf Sternberg (forthcoming). Personal and regional determinants of entrepreneurial activities: Empirical evidence from the Regional Entrepreneurship Monitor (REM) Germany. Jahrbuch für Regionalwissenschaft, Heft 1/2005. 
Table 1: The socio-demographic structure of nascent entrepreneurs and the adult population

\begin{tabular}{|c|c|c|c|c|}
\hline \multirow[b]{2}{*}{ Year } & \multicolumn{2}{|c|}{ Nascent Entrepreneur } & \multicolumn{2}{|c|}{ Adult Population } \\
\hline & 2001 & 2003 & 2001 & 2003 \\
\hline $\mathrm{N}$ & 272 & 437 & 7704 & 10000 \\
\hline \multicolumn{5}{|l|}{ Sex } \\
\hline \multirow[t]{2}{*}{ Female } & $31,5 \%$ & $36,7 \%$ & $49,4 \%$ & $49,6 \%$ \\
\hline & {$[25,9 \% \quad 37,0 \%]$} & {$[32,1 \% \quad 41,2 \%]$} & {$[48,3 \% \quad 50,5 \%]$} & {$[48,6 \quad 50,5 \%]$} \\
\hline \multirow[t]{2}{*}{ Age } & $38,5 \%$ & $37,9 \%$ & $41,7 \%$ & $41,5 \%$ \\
\hline & {$[37,1 \% 39,9 \%]$} & {$[36,9 \% 38,9] \%$} & {$[41,5 \%$} & {$[41,2 \%$} \\
\hline \multicolumn{5}{|l|}{ Marital status } \\
\hline \multirow[t]{2}{*}{ Unmarried } & $41,4 \%$ & $42,5 \%$ & $33,5 \%$ & $34,1 \%$ \\
\hline & {$[35,6 \% 47,4 \%]$} & {$[37,8 \% 47,2 \%]$} & {$[32,5 \% \quad 34,6 \%]$} & {$[33,1 \% 35,0 \%]$} \\
\hline \multirow[t]{2}{*}{ Married } & $45,4 \%$ & $48,3 \%$ & $53,4 \%$ & $53,9 \%$ \\
\hline & $51,4 \%]$ & {$[43,6 \% 53,1 \%]$} & {$[52,3 \%$} & {$[52,9 \%$} \\
\hline \multirow[t]{2}{*}{ Divorced } & $13,1 \%$ & $9,1 \%$ & $13,0 \%$ & $11,9 \%$ \\
\hline & {$[9,0 \% \quad 17,1 \%]$} & {$[6,4 \% \quad 11,8 \%]$} & {$[12,2 \% \quad 13,7 \%]$} & {$[11,3 \% \quad 12,5 \%]$} \\
\hline \multicolumn{5}{|l|}{ Education } \\
\hline \multirow[t]{2}{*}{ no exam } & & $0,4 \%$ & & $0,6 \%$ \\
\hline & & {$[-0,2 \% \quad 1,0 \%]$} & & {$[0,4 \quad 0,8]$} \\
\hline \multirow{2}{*}{$\begin{array}{l}\text { Extended elementary school } \\
\text { (Hauptschule) }\end{array}$} & & $22,2 \%$ & & $28,6 \%$ \\
\hline & & {$[18,2 \% \quad 26,1 \%]$} & & {$[27,7 \% \quad 29,5 \%]$} \\
\hline \multirow{2}{*}{$\begin{array}{l}\text { Junior high school } \\
\text { (Realschule, Mittlere Reife) }\end{array}$} & & $41,6 \%$ & & $40,3 \%$ \\
\hline & & {$[37,0 \% 46,2 \%]$} & & {$[39,4 \% \quad 41,3 \%]$} \\
\hline \multirow{2}{*}{$\begin{array}{l}\text { Senior high school } \\
\text { (Abitur, Fachabitur) }\end{array}$} & & $53,3 \%$ & & $41,5 \%$ \\
\hline & & {$[48,6 \% 58,0 \%]$} & & {$[40,6 \% 42,5 \%]$} \\
\hline \multirow{2}{*}{$\begin{array}{l}\text { dual training } \\
\text { (Lehre, Berufsausbildung) }\end{array}$} & & $54,3 \%$ & & $59,8 \%$ \\
\hline & & {$[49,6 \% 59,0 \%]$} & & {$[58,9 \% \quad 60,8 \%]$} \\
\hline \multirow[t]{2}{*}{ Master } & & $8,6 \%$ & & $6,9 \%$ \\
\hline & & {$[6,0 \% \quad 11,3 \%]$} & & {$[6,4 \% \quad 7,4 \%]$} \\
\hline University & & 46,1 & & $31,3 \%$ \\
\hline & & {$[41,4 \% 50,8 \%]$} & & {$[30,4 \% \quad 32,3 \%]$} \\
\hline Employment & & & & \\
\hline full-time working & $66,0 \%$ & $55,4 \%$ & $51,8 \%$ & $52,6 \%$ \\
\hline & {$[60,3 \% \quad 71,6 \%]$} & {$[50,8 \% 60,1 \%]$} & {$[50,7 \% \quad 53,0 \%]$} & {$[51,6 \% 53,6 \%]$} \\
\hline part-time working & $10,8 \%$ & $14,6 \%$ & $14,1 \%$ & $15,2 \%$ \\
\hline & {$[7,1 \% \quad 14,5 \%]$} & {$[11,2 \% \quad 17,9 \%]$} & {$[13,4 \% \quad 14,9] \%$} & {$[14,5 \%$} \\
\hline pupil, student & $10,4 \%$ & $8,3 \%$ & $8,7 \%$ & 8,9 \\
\hline & $14,0 \%]$ & $10,9 \%]$ & $9,4 \%]$ & {$[8,4 \%$} \\
\hline Housewife, retired & $6,0 \%$ & $6,9 \%$ & $18,9 \%$ & $15,6 \%$ \\
\hline & $8,8] \div$ & {$[4,5 \%$} & {$[18,0 \% \quad 19,8 \%]$} & {$[14,9 \% \quad 16,3 \%]$} \\
\hline Unemployed & 4,3 & 11,1 & 4,2 & 5,7 \\
\hline & $6,7 \%]$ & $14,1 \%]$ & $4,7 \%]$ & {$[5,2 \%$} \\
\hline Civilian or military service & $0,1 \%$ & $1,2 \%$ & $0,5 \%$ & $0,3 \%$ \\
\hline & {$[-0,3 \% \quad 0,5 \%]$} & {$[0,2 \%$} & {$[0,4 \%$} & {$[0,2 \%$} \\
\hline out of the labor force & $2,4 \%$ & $2,1 \%$ & $1,2 \%$ & $1,2 \%$ \\
\hline & {$[0,6 \% \quad 4,2 \%$} & {$[0,7 \%$} & {$[0,9 \%$} & {$[0,9 \%$} \\
\hline Household size & & & & \\
\hline one person & $23,9 \%$ & $23,1 \%$ & $20,8 \%$ & $20,0 \%$ \\
\hline & {$[18,8 \% 28,9 \%]$} & {$[19,1 \%$} & {$[19,9 \% \quad 21,7 \%]$} & {$[19,2 \% \quad 20,8 \%]$} \\
\hline two persons & $28,9 \%$ & $30,6 \%$ & $20,8 \%$ & $30,6 \%$ \\
\hline & {$[23,5 \% 34,4 \%]$} & {$[26,3 \%$} & $21,7 \%]$ & {$[29,7 \%$} \\
\hline more than two persons & $46,6 \%$ & $46,3 \%$ & $45,0 \%$ & $49,3 \%$ \\
\hline & {$[40,6 \% 52,6 \%]$} & {$[41,6 \%$} & $47,1 \%]$ & {$[48,4 \% 50,3 \%$} \\
\hline Net household income & & & & \\
\hline$<1500$ Euro & $21,3 \%$ & $17,9 \%$ & $22,3 \%$ & $18,7 \%$ \\
\hline & {$[16,4 \% \quad 26,2 \%]$} & {$[14,3 \% \quad 21,5 \%]$} & $23,2 \%]$ & {$[17,9 \% \quad 19,5 \%]$} \\
\hline$>=1500$ Euro \& $\quad<=3000 €$ & 34,2 & 40,6 & 41,3 & 39,1 \\
\hline & $39,8 \%]$ & {$[36,0 \% 45,2 \%]$} & {$[40,2 \%$} & {$[38,2 \% \quad 40,1 \%]$} \\
\hline$>=3000$ Euro & $32,7 \%$ & $35,0 \%$ & $20,5 \%$ & $29,6 \%$ \\
\hline & {$[27,1 \%$} & {$[30,5 \%$} & $21,5 \%]$ & {$[28,7 \%$} \\
\hline
\end{tabular}




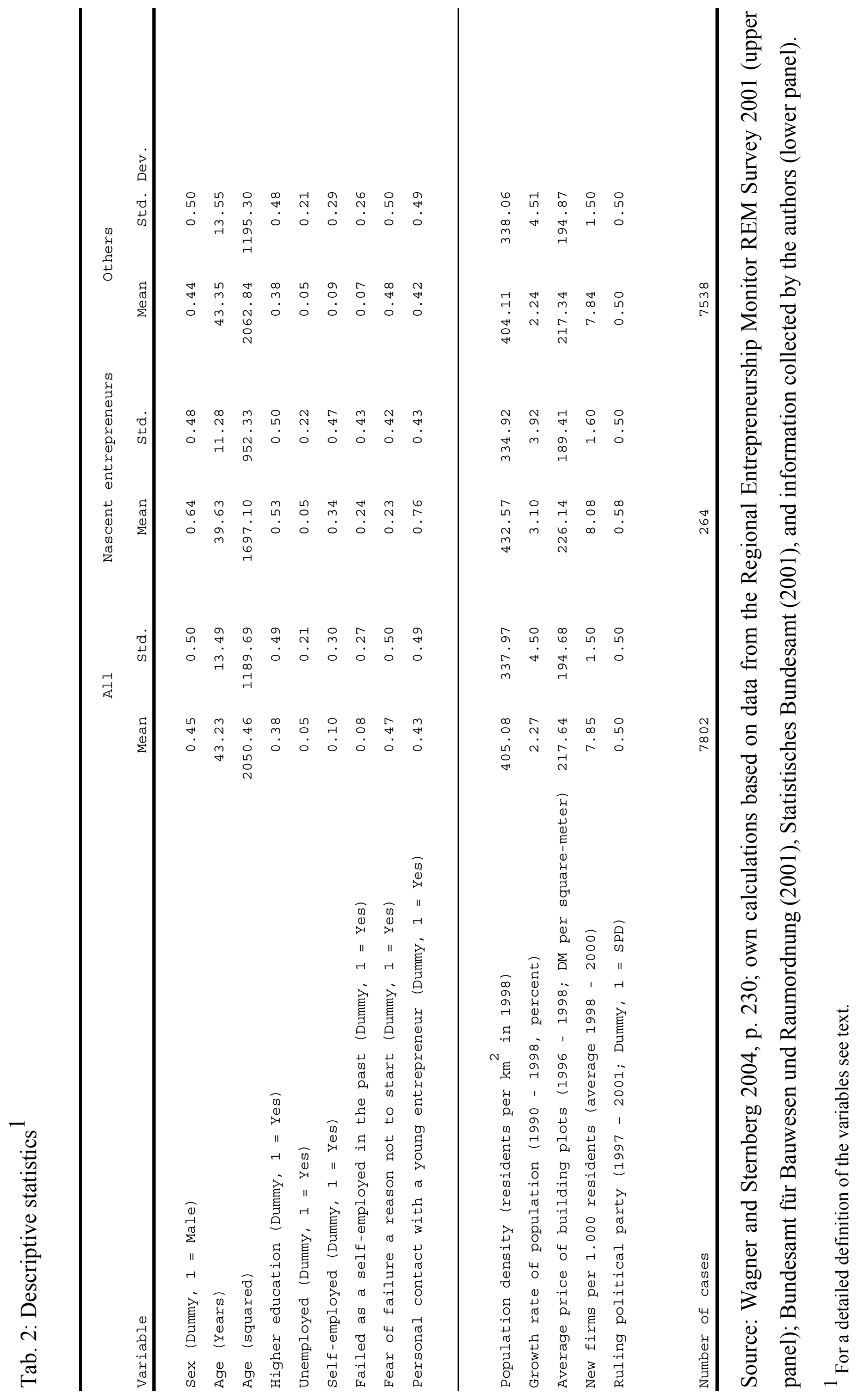




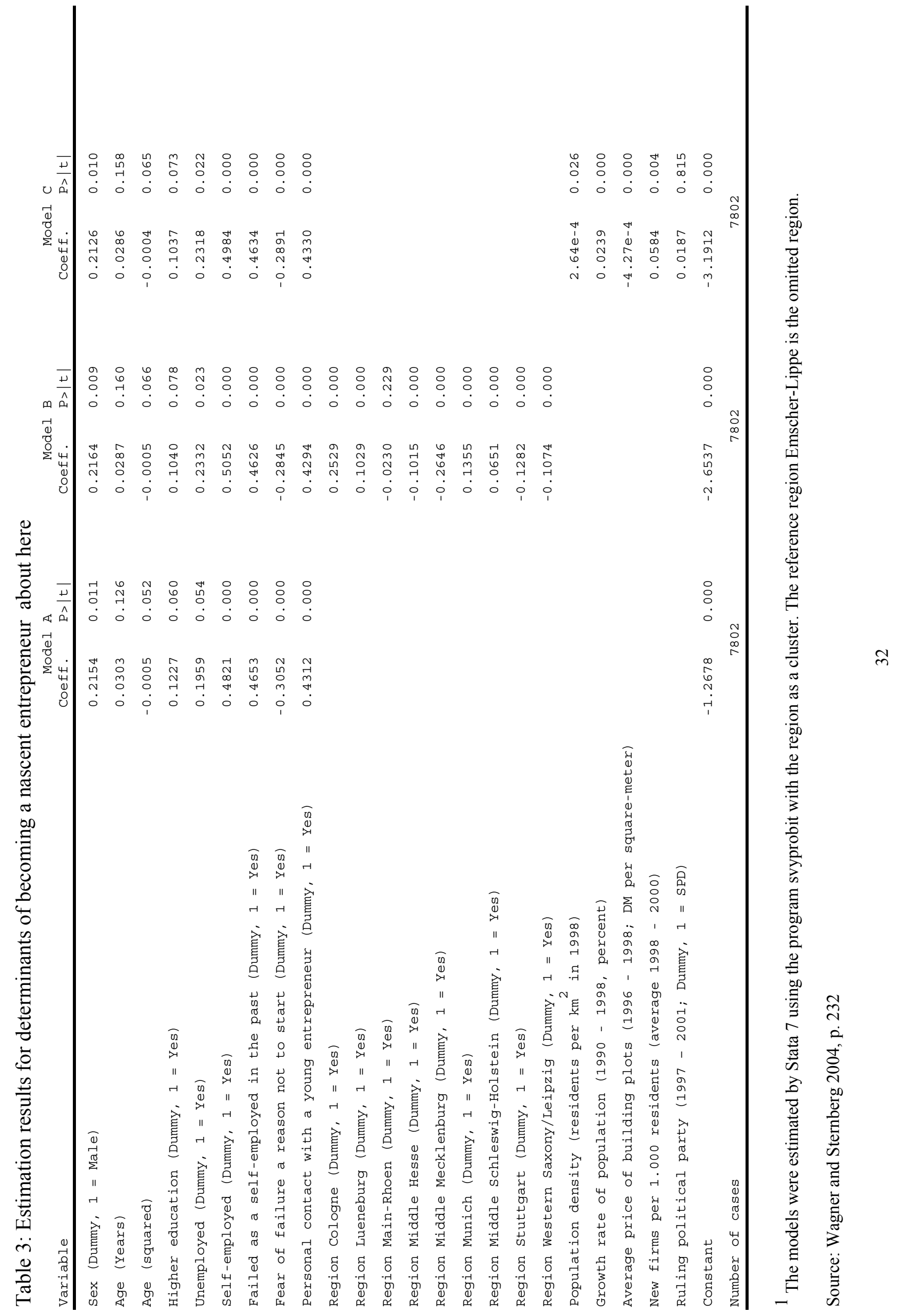

